\title{
27. FISSION TRACK DATING OF APATITE AND SPHENE FROM PALEOGENE SEDIMENTS OF DEEP SEA DRILLING PROJECT LEG 81, SITE 5551
}

\author{
I. R. Duddy and A. J. W. Gleadow, University of Melbourne Parkville \\ and \\ J. B. Keene, University of Sydney²
}

\begin{abstract}
Fission track ages of individual crystals of detrital apatite and sphene separated from early Eocene and Paleocene sandstones at Site 555 indicate the contribution of detritus from source rocks of at least three distinct age groups. A major group of Tertiary ( $56 \pm 3 \mathrm{~m} . \mathrm{y}$.) apatite ages is compatible with either contemporaneous or near contemporaneous volcanism or rapid unroofing of high level intrusives like those identified previously on Rockall Island (Jones et al., 1972 ) and Greenland (Gleadow and Brooks, 1979). Cretaceous (100 \pm 20 m.y.) apatite ages are consistent with known high level microgabbroic intrusives on Helen's Reef (Roberts et al., 1974). Such apatite ages could also be derived from basement rocks of very ancient terrains, especially around rifted continental margins where low level heating or uplift has affected the fission track ages of apatites (Gleadow, 1978).

Minor contributions were also identified from a terrain with apatite ages around 150 to 200 m.y. Similar ages are known from granitic and metamorphic rocks in Greenland (Gleadow, 1978; Gleadow and Brooks, 1979). From experience elsewhere in the North Atlantic Craton (Gleadow, 1978), such apatite ages are also likely in the basement rocks of Rockall, but direct fission track results are lacking.

With the identification of at least two nonmetamorphic sources, these data enable a refinement of the source of apatite suggested by heavy mineral studies (Morton, this volume).

Two distinct groups of sphene ages of around 60 and 1,380 m.y. are also consistent with sources either on the Rockall Bank (Roberts et al., 1973) or in Greenland (Gleadow, 1978).

Apatites from around $900 \mathrm{~m}$ depth have a combined age very close to the age of deposition, and they have track length distributions indicating that present temperatures in the hole are at, or close to, the maximum experienced since deposition.
\end{abstract}

\section{INTRODUCTION}

Leg 81 of the Deep Sea Drilling Project (DSDP) investigated the origin and evolution of the southwest margin of the Rockall Plateau (Fig. 1). Site 555 was one of four drilled during this leg and was the most easterly, being located on a saddle between Edoras Bank and Hatton Bank in water depth of $1659 \mathrm{~m}$. This hole reached a total sub-bottom depth of $964 \mathrm{~m}$, with only basalt and dolerite recovered below $927 \mathrm{~m}$. Coccoliths in the sediment at this depth indicate an age of late Paleocene (NP9: approx. 55 m.y.).

The gross sedimentary stratigraphy at Site 555 is relatively simple, with pelagic calcareous oozes of Recent to early Miocene age ( 0 to $281 \mathrm{~m}$ sub-bottom) overlying early Eocene and late Paleocene shelf and shallow marine facies consisting of sandstones and mudstones with considerable volcanogenic component. Some $646 \mathrm{~m}$ (281 to $927 \mathrm{~m}$ sub-bottom) of volcanogenic sediments were deposited in a relatively brief interval of time (NP9 to NP12, or approximately $4 \mathrm{~m}$.y.). Below $672 \mathrm{~m}$ sub-bottom the sediments are interbedded with submarine basaltic flows of tholeiitic composition. The volcanogenic sediments of Site 555 were deposited during the period

\footnotetext{
${ }^{1}$ Roberts, D. G., Schnitker, D., et al., Init. Repts. DSDP, 81: Washington (U.S. Govt. Printing Office).

2 Addresses: (Duddy, Gleadow) Department of Geology, University of Melbourne, Parkville, Australia 3052; (Keene) Department of Geology and Geophysics, University of Sydney, NSW, Australia 2006.
}

of rifting and initial seafloor spreading between Rockall and Greenland and according to Morton (this volume) are dominated by two heavy mineral suites: the first derived from basement rocks forming Rockall Bank, the second from a source in southern Greenland.

The purpose of this chapter is to present the results of fission track analysis of detrital apatite and sphene and to discuss the bearing of these results on provenance and the in situ thermal history of the sediments at Site 555 .

\section{TECTONIC SETTING AND PREVIOUS GEOCHRONOLOGY}

The Rockall Plateau is a continental fragment separated from Greenland to the west and the British Isles to the east by oceanic crust (Fig. 1). Separation from the British Isles probably took place in the Cretaceous (e.g., Bott, 1978), which would have effectively isolated the Tertiary sediments at Site 555 from detritus from the east.

Spreading of Greenland from the Rockall Plateau took place at about $52 \mathrm{~m} . \mathrm{y}$. and was preceded by a period of rifting with associated igneous activity (e.g., Roberts et al., 1979). All samples examined in this study were from sediments of NP9 to NP10 age and were deposited immediately prior to the spreading event. Possible source rocks for the sediments at Site 555 are restricted to the Rockall Plateau itself, Greenland to the west, and contemporaneous volcanic activity associated with rifting. 


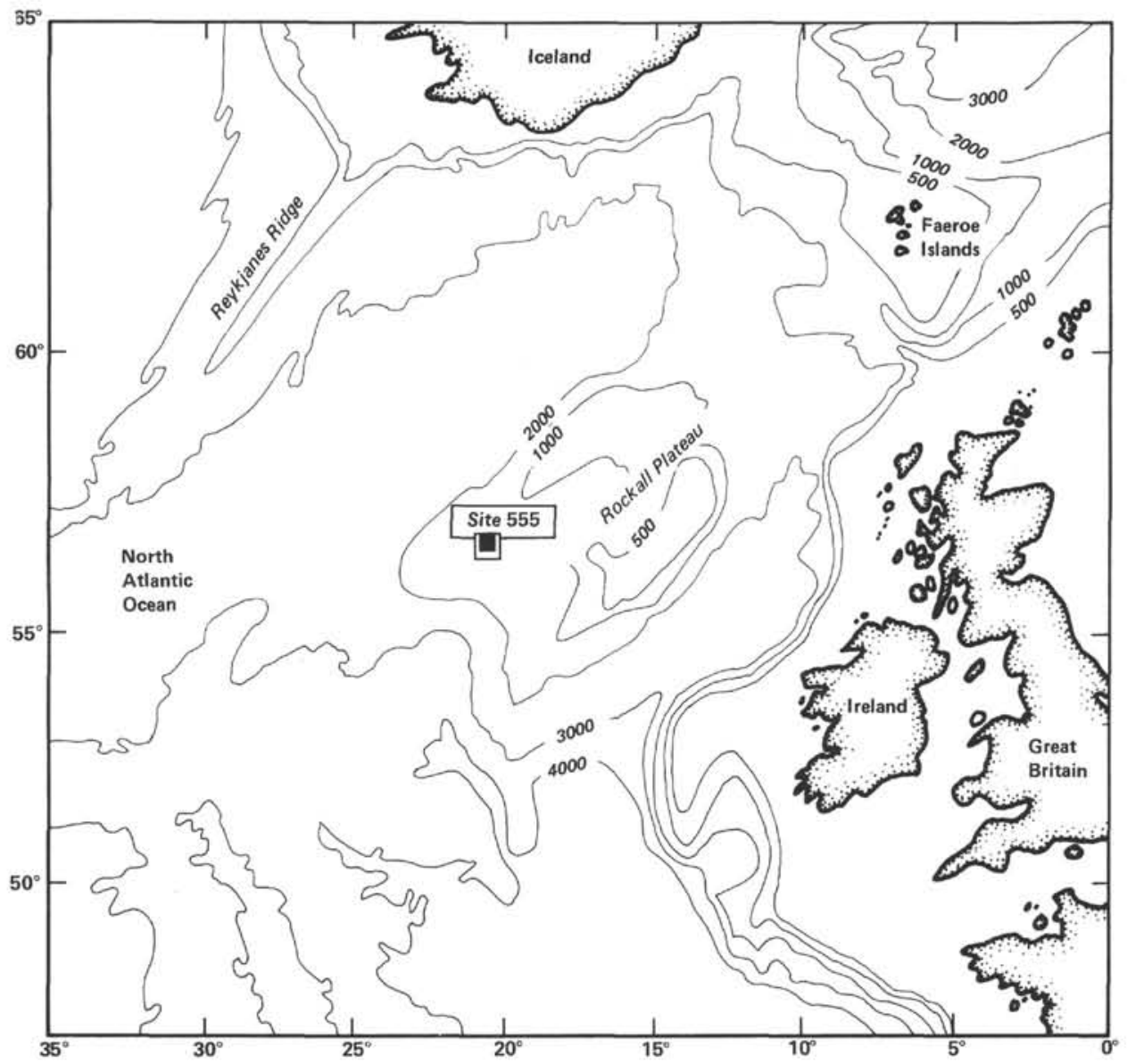

Figure 1. Location of Site 555 in relation to the Rockall Plateau and Iceland (depths in $\mathrm{m}$ ).

\section{SAMPLES}

Eight cores in sandstone intervals (combined into six samples) covering the depth range 336 to $919 \mathrm{~m}$ sub-bottom were examined in this study (Table 1).

\section{METHODS AND CONDITIONS}

Apatite and sphene were separated from the 90 to $300 \mu \mathrm{m}$ fraction of crushed and washed core by conventional heavy liquid and magnetic techniques and were dated by the external detector method (e.g., Gleadow and Brooks, 1979). The external detector method enables ages to be calculated on individual grains and thus allows different source components in a sediment to be identified. Apatites were mounted in epoxy resin on glass slides and etched in $5 \mathrm{~N} \mathrm{HNO}_{3}$ for $20 \mathrm{~s}$ at $20^{\circ} \mathrm{C}$.

Table 1. Sediment samples examined, Hole 555.

\begin{tabular}{cccc}
\hline $\begin{array}{c}\text { Sample } \\
\text { no. }^{a}\end{array}$ & $\begin{array}{c}\text { Core-Section } \\
\text { (level in cm) }\end{array}$ & $\begin{array}{c}\text { Sub-bottom } \\
\text { depth (m) }\end{array}$ & $\begin{array}{c}\text { Mineral } \\
\text { recovered }\end{array}$ \\
\hline R23101 & $32-6,35$ & 336.36 & Apatite \\
& $39-4,98$ & 400.49 & Apatite \\
R23098 & $61-1,143$ & 605.44 & Sphene \\
R23102 & $69, C C$ & 689 & Apatite \\
R23099 & $74, C C$ & 737 & Apatite \\
R23100 & $84-1,133$ & 823.84 & Apatite \\
R23103 & $92-2,44$ & 900.46 & Apatite \\
& $94-2,17$ & 919.19 & Apatite
\end{tabular}

\footnotetext{
a Numbers assigned by Department of Geology, University of Melbourne.
}

Sphenes were mounted in epoxy discs and etched in $50 \mathrm{~N} \mathrm{NaOH}$ at $130^{\circ} \mathrm{C}$ for $30 \mathrm{~min}$. Insufficient zircon was recovered for analysis.

Constants used in the calculation of ages and neutron dosimetry are given below (Table 2).

Horizontal confined fission track lengths were measured in apatite (Laslett et al., 1982).

\section{FISSION TRACK DATING RESULTS}

\section{Apatite and Sphene Ages}

Combined ages for apatite and sphene are given in Table 2 (1 sigma errors). These ages are calculated assuming all dated crystals in the sample were derived from a single source. At first glance the apatite results appear to indicate a range of ages varying from Tertiary (R23103: 900-919 m), and very close to the depositional age of the sediment, to Early Cretaceous (R23099: $737 \mathrm{~m}$ ). The single sample from which sufficient sphene was recovered contains seven grains in two distinct age groups: Tertiary ( $62 \pm 3$ m.y.) and pre-Cambrian $(1,381$ \pm 95 m.y.). The four grains that gave pre-Cambrian ages ranged from $1,158 \pm 147$ to $1,812 \pm 277$ m.y., and are considered to belong to a single group given the large errors. With two sigma errors, the Tertiary sphene age is considered to be not significantly different from the youngest apatite age.

Most of the combined apatite ages have no geological meaning, however, as is illustrated by a series of histo- 
Table 2. Combined ages for apatite and sphene.

\begin{tabular}{|c|c|c|c|c|c|c|c|c|}
\hline $\begin{array}{c}\text { Sample } \\
\text { no. } .^{\mathrm{a}}\end{array}$ & Mineral & $\begin{array}{c}\text { Number } \\
\text { of } \\
\text { grains }\end{array}$ & $\begin{array}{c}\text { Neutron } \\
\text { dose } \\
\left(\times 10^{15}\right. \\
\left.\mathrm{n} \cdot \mathrm{cm}^{-2}\right)\end{array}$ & $\begin{array}{c}\text { Fossil } \\
\text { track } \\
\text { density } \\
\left(\times 10^{6} \mathrm{~cm}^{-2}\right)\end{array}$ & $\begin{array}{c}\text { Induced } \\
\text { track } \\
\text { density } \\
\left(\times 10^{6} \mathrm{~cm}^{-2}\right)\end{array}$ & $\begin{array}{l}\text { Correlation } \\
\text { coefficient }\end{array}$ & $\begin{array}{l}\mathrm{Age}^{\mathrm{b}} \\
\text { (m.y.) }\end{array}$ & $\begin{array}{c}\text { Uranium } \\
\text { (ppm) }\end{array}$ \\
\hline R23103 & Apatite & 10 & 9.903 (2366) & $0.938(303)$ & $10.38(1677)$ & 0.948 & $53 \pm 4$ & 42 \\
\hline R23102 & Apatite & 10 & $9.954(2366)$ & $1.246(334)$ & $8.983(1204)$ & 0.964 & $82 \pm 5$ & 36 \\
\hline R23101 & Apatite & 10 & $10.01(2366)$ & $0.673(242)$ & 3.874 (697) & 0.981 & $104 \pm 8$ & 15 \\
\hline R23100 & Apatite & 11 & $10.06(2366)$ & $2.342(860)$ & $12.61(2316)$ & 0.825 & $111 \pm 5$ & 50 \\
\hline R23099 & Apatite & 9 & $10.11(2366)$ & $0.807(352)$ & $4.044(882)$ & 0.820 & $120 \pm 8$ & 16 \\
\hline R23098 & Sphene & 4 & $4.277(2193)$ & 35.23 (1643) & $5.853(273)$ & 0.798 & $1381 \pm 95$ & 55 \\
\hline R23098 & Sphene & 3 & $4.277(2193)$ & $5.978(697)$ & $24.46(1426)$ & 0.999 & $62 \pm 3$ & 229 \\
\hline
\end{tabular}

grams of single crystal ages given in Figure 2. For most samples the single crystals cover a wide range of ages, which is inconsistent with a single source. On the other hand the deepest sample (R23103), with the youngest combined apatite age, has the smallest spread in single crystal ages and is considered to have been dominantly derived from one source. It is also clear that the shallowest sample (R23101) is composed mainly of single crystals of Cretaceous age. Sample R23102 contains crystals consistent with members of both age groups as do R23099 and R23100. In addition these latter two samples contain a total of five crystals that compose at least one other distinct group with a mean age of about 200 m.y. The composite histogram (Fig. 2) of all single-grain ages illustrates these groups, which give combined ages (1 standard deviation of the individual crystal ages) of 56 $\pm 3,97 \pm 3$, and $199 \pm 13$ m.y., respectively. Given the errors (about 10\%) on single crystal ages, these groups should be considered somewhat arbitrary, although the occurrence of dominantly Tertiary and Cretaceous ages in individual samples does provide support for the occurrence of these two groups.

\section{Track Length Distributions}

Distributions of confined fission track lengths in apatites from five samples are given in Figure 3. These lengths were gathered from a larger number of grains than those dated and therefore are derived from a variable mixture of grains of different ages particularly in the samples from 689,737 , and $823 \mathrm{~m}$. The distribution of ages in the top (336-400 m) and bottom (900-919 m), however, suggests that these lengths were mainly gathered from apatites with Cretaceous and Tertiary ages, respectively - and only these will be considered in the detailed discussion that follows.

\section{DISCUSSION}

\section{Provenance of the Eocene Sediments}

Broadly speaking apatite fission track ages indicate the time at which the host sample cooled below about $100^{\circ} \mathrm{C}$. For rapidly cooled rocks, a fission track age will be essentially concordant with radiometric methods such as $\mathrm{Rb} / \mathrm{Sr}$ and $\mathrm{K} / \mathrm{Ar}$. In slowly cooled rocks, apatite fission track ages will always be significantly younger than these other techniques, while zircon and sphene fission track ages will be older and may be similar to $\mathrm{K} / \mathrm{Ar}$ and $\mathrm{Rb} /$ Sr ages.
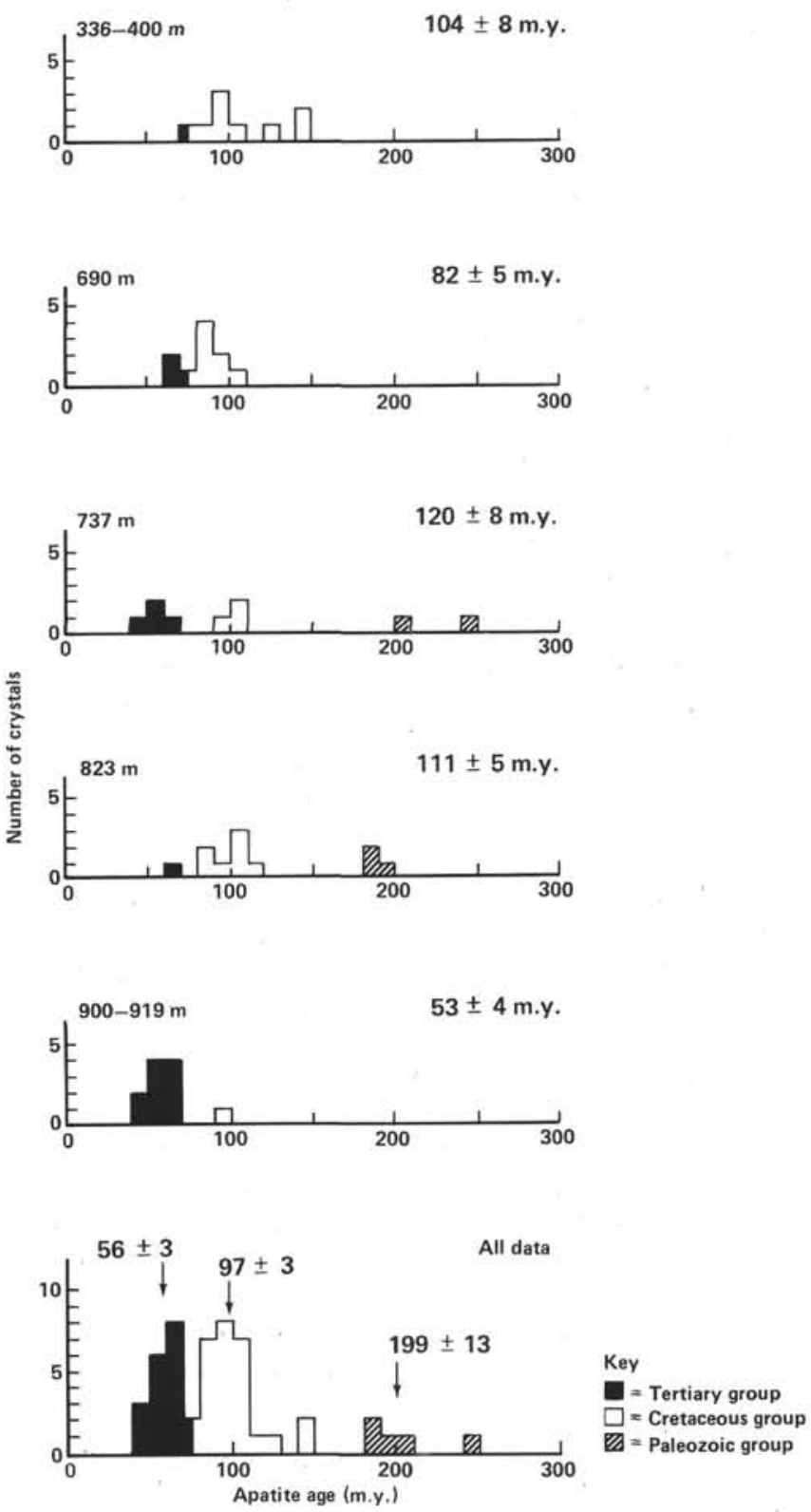

Figure 2. Histograms of single-crystal apatite fission track ages for samples at DSDP Site 555. Three distinct age groups are distinguished, the youngest of which is close to the age of the sediments in this section of the hole. In general the combined age for each sample has no actual geological meaning as it is a mixture of ages from different sources. 

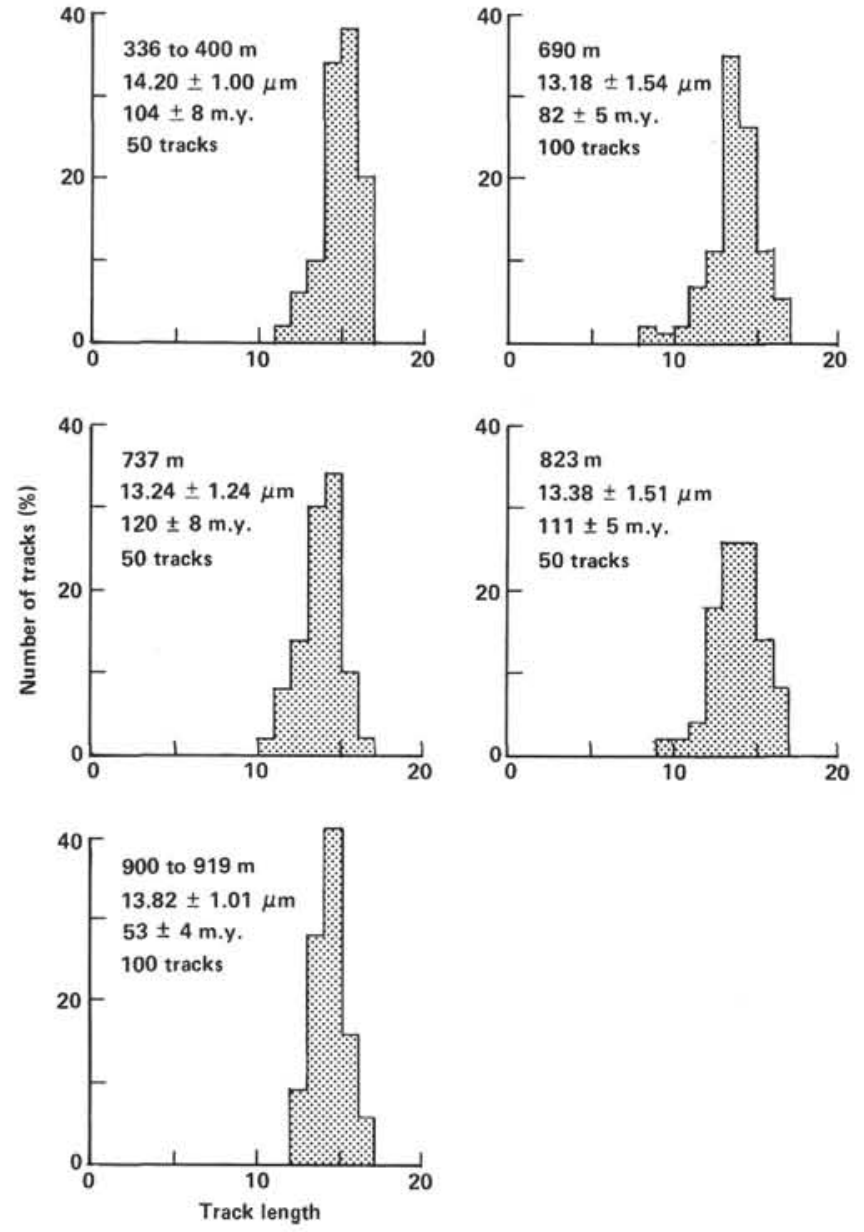

Figure 3. Distributions of apatite fission track lengths for dated samples shown in Figure 2. The length distribution for the deepest sample is consistent with the present temperature being the maximum experienced since deposition. Approximate sample depth, mean length, and combined apatite fission track ages are also given.

On this basis, the similar Tertiary apatite and sphene ages are compatible with known igneous source rocks on Rockall (Jones et al., 1972) and in Greenland (Gleadow and Brooks, 1979). Similarly, a source with Cretaceous apatite ages possibly comprises the high level microgabbroic intrusives at Helen's Reef on the Rockall Plateau (Roberts et al., 1974).

No direct fission track data are available for sources of the oldest apatite ages (approximately 200 m.y.) on Rockall, although comparable apatite ages are known from Caledonian intrusives and basement rocks on Greenland (Gleadow and Brooks, 1979). Gleadow (1978) has shown that such ages are likely in basement intrusive and metamorphic rocks on continental margins as a result of the widespread low-level heating effects associated with rifting. Thus such ages are equally possible in the preCambrian basement rocks of the Rockall Plateau itself (Miller et al., 1973; Roberts et al., 1973).

The sphene age of 1,381 \pm 95 is compatible with the dated granulites on Rockall north of the Grenville front (Roberts et al., 1973), but again such ages are also known in Greenland (Gleadow, 1978).
We conclude that the dated apatite and sphene from Site 555 may have been entirely derived from the Rockall Plateau, but that a more distant source in Greenland is also possible for some crystals.

Morton (this volume) has identified two significant source regions for the sediments dealt with in this study on the basis of the distributions of a suite of heavy minerals including apatite. He believed the apatite to be mainly derived from metamorphic basement rocks of the Rockall Plateau. The fission track results indicate that at least three distinct sources of apatite were available and that the youngest age group could have been derived from rift-associated contemporaneous volcanic activity. Volcanism of intermediate or acid type would have been necessary to provide apatite and sphene since these minerals are generally absent from basaltic rocks. Volcanogenic material of this character is certainly not obvious in the sandstones, although the pyroxenes and pargasitic amphiboles identified by Morton (this volume) and abundant biotite noted in the sample studied here are consistent with intermediate pyroclastic volcanism, as well as with the metamorphic sources he favored.

Morton's detailed heavy mineral work suggests a variable mixture of Greenland- and Rockall-derived detritus for most of the section below about $336 \mathrm{~m}$ sub-bottom at Site 555. This level corresponds closely with the proposed separation of Greenland from the Rockall Plateau, above which Morton identifies only that detritus compatible with a local Rockall source. Future dating of apatite from samples above this source change noted by Morton may clarify the possible contribution of Greenland source rocks to the three distinct age groups identified here.

\section{Post-Depositional Thermal History of Site $\mathbf{5 5 5}$}

The principles governing the interpretation of track length distributions in apatite are discussed in detail elsewhere (Gleadow et al., 1983 and in prep.) and are only briefly outlined here. Apatites in rocks that have rapidly cooled from temperatures above about $125^{\circ} \mathrm{C}$ (i.e., volcanics or high level intrusives) have fission track length distributions that are narrow, with mean lengths greater than about $14 \mu \mathrm{m}$. If such rocks, or derived apatites, are subsequently buried, the tracks in apatite are shortened in a regular way with increasing temperature, reaching approximately $13 \mu \mathrm{m}$ at temperatures of $70^{\circ} \mathrm{C}$. This decrease in mean length occurs without a large increase in dispersion of the length distribution. At temperatures between $70^{\circ}$ and $125^{\circ} \mathrm{C}$, tracks rapidly fade to zero length with an associated large increase in the dispersion of the length distribution.

Fission track length distributions in apatites from slowly cooled rocks (e.g., granites or slowly uplifted metamorphic rocks) spend a significant portion of their uplift history at temperatures within the track annealing zone $\left(70^{\circ}\right.$ to $\left.125^{\circ} \mathrm{C}\right)$, which significantly shortens those tracks being continually produced in this zone. These length distributions are thus characteristically broad and skewed.

The narrow distribution and the mean length of tracks for the mainly Tertiary apatites in R23103 (Fig. 3) indicate 
both that the original source rock was cooled rapidly and that the sample has not subsequently suffered temperatures greater than about $50 \pm 5^{\circ} \mathrm{C}$ (Gleadow et al., 1983).

Similarly the lengths from sample R23101 containing mainly apatites of Cretaceous age are not consistent with any heating greater than that experienced at the present.

Apatite track lengths from the remaining samples are more variable and suggest the combination of lengths from apatites from rapidly (long lengths) and more slowly cooled (shorter lengths) rocks.

\section{CONCLUSIONS}

The distribution of apatite and sphene ages in the Eocene-Paleocene sediments at Site 555 suggest the following main conclusions:

1. The three distinct apatite fission track age groups present in the hole are compatible with derivation of detritus from the Rockall Plateau itself or Greenland.

2. The youngest group of apatites has a Tertiary age close to the age of the sediments and may have been derived from intermediate to acid contemporaneous volcanism associated with rifting.

3. The fission track ages and the distribution of track lengths from samples near the base of the hole indicate that the present temperatures are at or near the maximum experienced since deposition.

\section{REFERENCES}

Bott, M. H. P., 1978. The origin and development of the continental margins between the British Isles and southeastern Greenland. In
Bowes, D. R., and Leake B. E. (Eds.), Crustal Evolution in Northwestern Britain and Adjacent Regions: Liverpool (Steel House Press) pp. 377-392.

Gleadow, A. J. W., 1978. Fission track evidence for the evolution of rifted continental margins. Short papers of the Fourth Int. Conf. Geochron. Cosmochron. Isotope Geol., U.S. Geol. Surv. OpenFile Report 78-101, pp. 143-145.

Gleadow, A. J. W., and Brooks, J. F., 1979. Fission track dating, thermal history and tectonics of igneous intrusions in East Greenland. Contrib. Mineral. Petrol., 71:45-60.

Gleadow, A. J. W., Duddy, I. R., and Lovering, J. F., 1983. Fission track analysis: A new tool for the evaluation of thermal histories and hydrocarbon potential. APEA J., 23:93-102.

Jones, E. J. W., Mitchell, J. G., Shido, F., and Phillips, J. D., 1972. Igneous rocks dredged from the Rockall Plateau. Nature, Phys. Sci., 237:118-120.

Laslett, G. M., Kendall, W. S., Gleadow, A. J. W., and Duddy, I. R., 1982. Bias in the measurement of fission track length distributions. Nucl. Tracks, 6:79-85.

Miller, J. M., Roberts, D. G., and Mathews, D. H., 1973. Rocks of Grenville Age from Rockall Bank. Nature, Phys. Sci., 246:61.

Roberts, D. G., Ardus, D. A., and Dearnley, R., 1973. Pre-Cambrian rocks drilled from the Rockall Bank. Nature, Phys. Sci., 244: 21-23.

Roberts, D. G., Flemming, N. C., Harrison, R. K., Binns, P. E., and Snelling, N. J., 1974. Helen's Reef: A microgabbroic intrusion in the Rockall intrusive centre, Rockall Bank. Mar. Geol., 16:21-30.

Roberts, D. G., Montadert, L., and Searle, R. C., 1979. The western Rockall Plateau: Stratigraphy and structural evolution. In Montadert, L., Roberts, D. G., et al., Init. Repts. DSDP, 48: Washington (U.S. Govt. Printing Office), 1061-1088.

Date of Acceptance: September 9, 1983 